\title{
No Need to Throw in the Towel Yet: The Case for the Revival of South African Textile and Clothing Industries
}

\author{
Prof. Ogutu Miruka
}

\author{
Associate Professor, Graduate School of Business \& Government Leadership \\ North-West University, Mafikeng, South Africa \\ Email: mirukaco@gmail.com
}

\section{Doi:10.5901/mjss.2014.v5n7p11}

\section{Abstract}

Despite the unexciting outlook of the textile and clothing industries in South Africa today, the strategic relevance of the sub sector in terms of developing country macroeconomic policies makes it imperative that radical interventions be explored in order to save it from total collapse. For instance, the sub sector has one of the longest supply chain that includes production of raw materials; spinning, weaving, or knitting; finishing; design; sewing; distribution; and marketing. Another factor that should make the sub sector attractive to policy makers is the fact that it absorbs a high proportion of unskilled workers and is generally labour intensive not to mention the fact that it is also female friendly. The paper demonstrates that the industry is worth governmental support and active intervention and should not be left to the mercies of the international market forces that presently threaten to wipe it out.

\section{Introduction}

The South African Textiles and Clothing industries are presently extremely vulnerable to job losses and concomitant factory closures due to a number of competitive pressures. Domestically, cotton and yarn prices continue to rise on yearon-year basis and are out of phase with comparable sources internationally. A militant labour union emboldened by a sometimes pliant government also makes for tough bargaining in the labour market. The export component of the clothing industry is similarly on dire straits given the internationally dwindling margins and the fierce competition from other emerging markets.

These trends make it increasingly difficult to make accurate market forecasts for the sub sector. Forecasts have to factor in looming concerns about trade restrictions, militant unions, scarce skills, investment in technology, physical infrastructure provision, an increasing slow-down of production, high import penetration and a consolidation of business investment amongst other factors. Added to the aforementioned factors, one has also to consider the often devastating effects that an unexpected recession has on the textiles and clothing sector. For instance, every sector of the textiles and clothing industry is still reeling from the recent global recession of 2008 and the attendant macroeconomic trends. As will be shown subsequently, nearly every positive industrial analysis indicator begun to dip or worsened its downward trend after 2008. These developments have begun to beget fundamental and widespread changes in the economic landscape of the sub sector.

While there is no gain saying the fact that great efforts are being made by many countries all over the world to work through common trade problems such as tariff barriers and inward-looking macroeconomic policies, a lot still needs to be done in order to achieve long-term competitiveness while at the same time paying due respect to emerging global business trends. It is against this back ground that I undertake a review of the past performance of the industries in the last twenty years in order to try and explain the determinants of performance in the industry and the policy implications thereof. The survey will be carried out in five broad themes beginning with industrial output. Second, we will look at the data regarding Value Added and follow up on that by looking at Employment Capacity. The final two sections will then deal with Investments and Trade. A concluding section will then be provided to synthesise the research problem and offer a way forward.

\section{Industrial Output}

In terms of real output prices taking 2005 as the base year, both textiles and clothing show marginal increase from 1992 
till around the year 2000 with minimal bumps ${ }^{1}$. During this period, as shown in Figure 2.2 below, textiles performed marginally better than clothing. However, from the year 2000 , clothing takes a marginal dip in output while textiles overcomes clothing for the first time and this superior performance in real output against clothing persists till 2010. From the year 2000 onwards, textiles outperforms clothing by double the difference in the previous period and this difference is remarkable in that it is maintained even when both industries begin to shed output first marginally in 2004 and later on even more sharply from 2008.

Figure 2.1: Real Output in Rm 2005 Prices

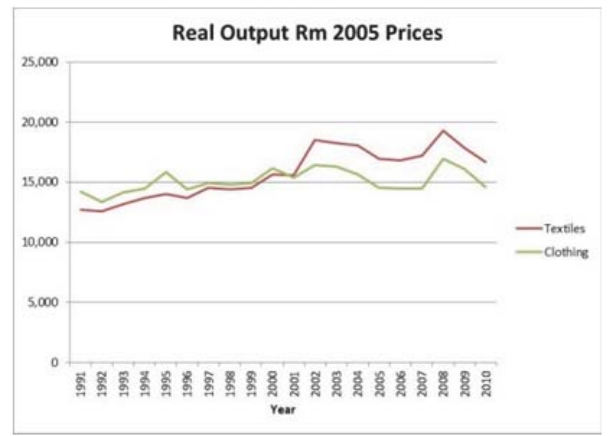

If, as Wignaraja (2008, p. 30) avers, technological capabilities as well as relevant skills that match the best available internationally are important determinants of competitiveness, then these factors would not seem to be available in sufficient quantities given the performance of the industries after the expiry of the Multi-fibre Agreement (MFA). January 1, 2005 was to mark the lifting of quotas which had hitherto governed the global trade on textiles and clothing under the Multi-fibre Agreement (MFA) which came into force in 1974. As expected, there is a marginal decline in output at this stage probably owing to the entry of low cost locales in the traditional markets of South African textiles especially domestically as well as in Europe and the US (United States of America).

Nevertheless, the temporary re-imposition of quotas on Chinese exports by developed countries as well as by some developing countries taking advantage of safeguard measures agreed to by China in negotiations with the World Trade Organization (WTO) prior to attaining membership seems to have arrested this trend in 2006. Thus, we witness once again a surge in output in both industries between 2006 and 2008. Two significant events happened in 2007 and in 2008 that might help explain the ominous nosedive we witness from 2008. Vietnam, a major low cost producer, joined the WTO in January 11, 2007 without any restrictions on her textile and clothing exports thereby adding considerably to competitive pressures on small producers. The year 2008 also saw the expiry of the safeguard measures that had been slapped on China thus making South African textile and clothing output even more vulnerable.

Figure 2.2: Value of Textiles and Related Articles as a \% of Total Export Value

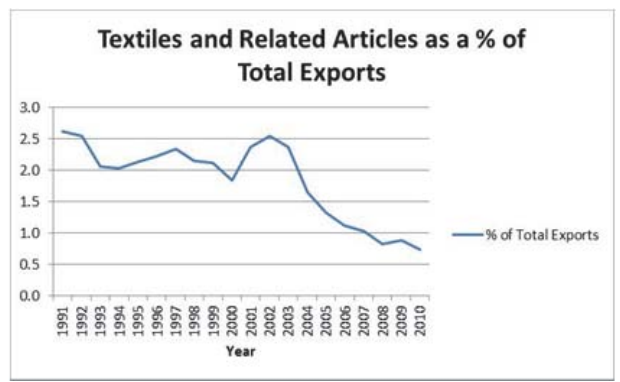

${ }^{1}$ All data referred to in this chapter are obtained from Quantec: http://www.quantec.co.za/subscriptions unless otherwise stated. Data accessed between March and July 2011. 
Table 2.1: Textile Industry Trends²

\begin{tabular}{|c|c|c|c|c|c|c|}
\hline Year & $\begin{array}{c}\text { Real Remuneration per } \\
\text { Employee }\end{array}$ & $\begin{array}{c}\text { Unit Labor } \\
\text { Cost }\end{array}$ & $\begin{array}{c}\text { Labor } \\
\text { Productivity }\end{array}$ & $\begin{array}{c}\text { Capital Labor } \\
\text { ratio }\end{array}$ & $\begin{array}{c}\text { Capacity } \\
\text { Utilization }\end{array}$ & $\begin{array}{c}\text { Net } \\
\text { Markup }\end{array}$ \\
\hline 1991 & 30,752 & 87.31 & 67.97 & 76.08 & Missing & 1.0 \\
\hline 1992 & 31,009 & 89.06 & 69.88 & 79.67 & Missing & 1.2 \\
\hline 1993 & 31,629 & 80.28 & 74.68 & 87.85 & Missing & 1.7 \\
\hline 1994 & 33,268 & 89.83 & 75.87 & 84.87 & Missing & 1.3 \\
\hline 1995 & 33,921 & 96.52 & 75.41 & 84.05 & Missing & 1.0 \\
\hline 1996 & 31,934 & 107.35 & 65.33 & 76.62 & 86.41 & -1.2 \\
\hline 1997 & 32,465 & 108.09 & 70.14 & 78.14 & 84.51 & -0.1 \\
\hline 1998 & 36,928 & 117.73 & 78.20 & 95.25 & 86.10 & -1.4 \\
\hline 1999 & 36,712 & 108.80 & 78.53 & 100.56 & 88.65 & -1.9 \\
\hline 2000 & 35,028 & 100.77 & 73.44 & 96.42 & 88.32 & -2.5 \\
\hline 2001 & 33,429 & 98.43 & 72.24 & 92.68 & 86.99 & -2.1 \\
\hline 2002 & 31,224 & 89.58 & 77.04 & 86.83 & 88.42 & 0.5 \\
\hline 2003 & 29,668 & 96.60 & 70.55 & 85.63 & 87.63 & -0.4 \\
\hline 2004 & 33,715 & 100.96 & 88.48 & 91.00 & 92.55 & 1.9 \\
\hline 2005 & 35,905 & 100.00 & 100.00 & 100.00 & 82.55 & 2.9 \\
\hline 2006 & 37,401 & 101.94 & 106.29 & 99.80 & 83.63 & 3.6 \\
\hline 2007 & 39,814 & 111.82 & 109.71 & 92.15 & 83.18 & 3.9 \\
\hline 2008 & 44,406 & 109.70 & 124.61 & 92.31 & 82.60 & 4.3 \\
\hline 2009 & 46,526 & 125.15 & 129.83 & 90.68 & 79.88 & 4.7 \\
\hline 2010 & 47,899 & 136.91 & 140.15 & 87.60 & 77.15 & 6.6 \\
\hline
\end{tabular}

During the period under consideration, from 1991 to 2010, the ratio of textiles and related articles export value as compared to total export value saw a constant decline that was only arrested once between the year 2000 and 2002. The percentage points reduced from a high of $2.6 \%$ in 1991 to $0.7 \%$ in the year 2010 (see Figure 2.2). Thus, it would seem as textiles and clothing represent a less significant component of South African export trade than it did two decades ago. Nevertheless, the government is still keen on supporting the sector given its historical significance and the strategic nature of the industry considering the country's developmental ambitions as well as the strength of the labour unions.

Table 2.2: Clothing Industry Trends ${ }^{3}$

\begin{tabular}{|c|c|c|c|c|c|c|}
\hline Year & $\begin{array}{c}\text { Real Remuneration per } \\
\text { Employee }\end{array}$ & $\begin{array}{c}\text { Unit Labor } \\
\text { Cost }\end{array}$ & $\begin{array}{c}\text { Labor } \\
\text { Productivity }\end{array}$ & $\begin{array}{c}\text { Capital Labor } \\
\text { ratio }\end{array}$ & $\begin{array}{c}\text { Capacity } \\
\text { Utilization }\end{array}$ & $\begin{array}{c}\text { Net } \\
\text { Markup }\end{array}$ \\
\hline 1991 & 26,572 & 44.05 & 98.19 & 140.20 & Missing & 5.5 \\
\hline 1992 & 26,336 & 50.90 & 96.21 & 135.42 & Missing & 5.3 \\
\hline 1993 & 28,235 & 62.55 & 104.47 & 120.13 & Missing & 6.7 \\
\hline 1994 & 27,230 & 63.13 & 102.47 & 114.41 & Missing & 7.3 \\
\hline 1995 & 28,124 & 66.87 & 104.20 & 108.57 & Missing & 7.0 \\
\hline 1996 & 25,390 & 75.92 & 87.05 & 102.63 & 83.90 & 4.3 \\
\hline 1997 & 26,322 & 72.21 & 94.69 & 109.01 & 84.00 & 5.7 \\
\hline 1998 & 29,260 & 84.59 & 95.38 & 115.40 & 81.47 & 2.2 \\
\hline 1999 & 29,990 & 92.26 & 90.41 & 109.60 & 84.10 & -0.4 \\
\hline 2000 & 28,931 & 81.55 & 97.09 & 106.81 & 82.37 & 2.8 \\
\hline 2001 & 26,249 & 81.14 & 88.81 & 101.54 & 80.67 & 2.9 \\
\hline 2002 & 25,446 & 85.46 & 90.39 & 97.92 & 83.77 & 4.2 \\
\hline 2003 & 27,058 & 91.45 & 96.82 & 98.16 & 78.04 & 4.8 \\
\hline 2004 & 26,868 & 98.00 & 95.57 & 94.06 & 80.65 & 4.7 \\
\hline 2005 & 27,293 & 100.00 & 100.00 & 100.00 & 82.20 & 5.4 \\
\hline 2006 & 28,826 & 106.76 & 104.78 & 96.22 & 85.73 & 5.5 \\
\hline 2007 & 31,129 & 111.20 & 113.37 & 97.55 & 83.78 & 6.1 \\
\hline 2008 & 36,522 & 97.90 & 138.35 & 113.57 & 80.73 & 6.6 \\
\hline 2009 & 41,560 & 108.34 & 163.33 & 124.31 & 71.48 & 8.5 \\
\hline 2010 & 42,002 & 121.03 & 166.63 & 117.32 & 71.48 & 9.9 \\
\hline
\end{tabular}

${ }^{2}$ At Rand 2005 constant prices while Indices are taken at $2005=100$

${ }^{3}$ At Rand 2005 constant prices while Indices are taken at $2005=100$ 
As is apparent from a casual glance of Tables 2.1 and 2.2, industry performance data since the Agreement on Textiles and Clothing (ATC) expiry on January 1, 2005 does nothing to dispel the grimmest prognostications of local stakeholders and academic commentators. The dramatic increases in Chinese market shares in European destinations that previously sourced from South Africa are a big threat for the domestic textile and clothing industry internationally. The situation is no different domestically given the high import penetration of the market again by the selfsame Chinese.

This performance forces one to again consider theories of comparative advantage which as Wignaraja (2008, pp. 30 -31) points out, 'can be firm-specific determining not only which countries will enjoy a comparative advantage in international markets but also which firms can exploit that comparative advantage better than others.' The author points out that a number of factors may determine the nature of this comparative advantage ranging from the type of firm ownership, firm size, market-orientation, human capital, location, the technology deployed as well as technological linkages with other firms and support institutions amongst other factors. Throughout the chapter, we will continue to look at these factors either separately or jointly under other themes in order to tease out questions that can direct research to plausible explanations of performance. In the next section, we will look at the nature of value addition in the sub sector.

\section{Value Added}

Value addition in any industry can be impacted on by a number of factors. In the South African textile and clothing industries, one might expect the value addition to be suboptimal given the much cited inefficiency (low productivity) of the workers compared with competitors such as China, Cambodia, Turkey, Pakistan, India and Vietnam to mention but a few. Lack of training or general skills deficit is another suspect contributing to low value addition. Militant industrial relations may also play a part in reducing value addition. Other factors one might mention include the currently rising energy costs as well as infrastructure and logistic shortcomings. Barnes et al. (2001, pp. 294 - 295) cite Normann and Ramirez (1993) to emphasize what they call a value constellation rather than a value chain:

In the Fordist era, firms sought to position themselves in the value chain in such a way as to maximise the value they could add during the production process. Firms that wish to survive in the competitive post-Fordist industrial era, however, must go beyond adding value in production to looking for new ways to create value for their customers - be they the end consumer or intermediate producers.

This idea of value creation will be explored further in the research to show areas within the sun sector where optimal results can be obtained. This is because value addition in the sub sector has, comparatively, been quite modest. Based on 2005 prices in millions of rands, it took nearly fifteen years for the value added of the two industries to surpass the levels obtaining in 1991. As shown in Figure 2.4 in the next page, there was a marked decline in value addition from 1991 to the year 1993. In the next four years, the value addition picked up and irregularly rose to 1991 levels in the year 1997 before plunging to a new low in the year 2000. This was followed by an eight year period of irregular growth that reached its peak in 2008 when a negative trend commenced once again. Nearly all the movements in value addition for the twenty-year period covered were caused by the textile industry as the clothing industry contribution remained more or less constant.

Figure 2.4: Real Value Added in Rm at 2005 Prices

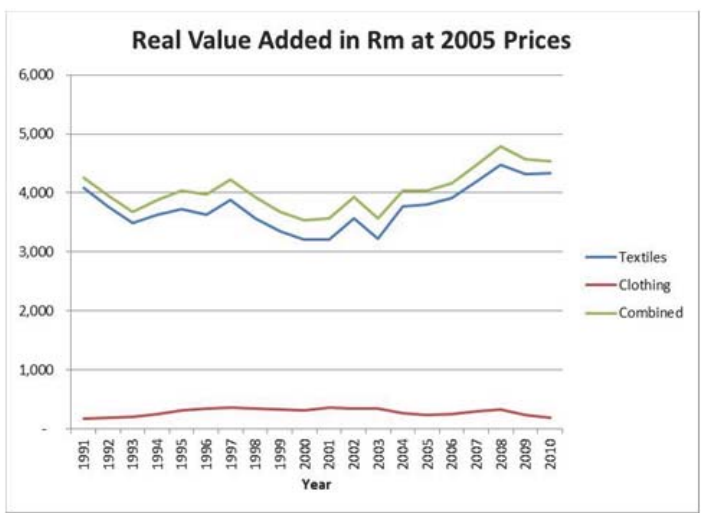


Barnes et al. (2001, p. 295), in a study looking at manufacturing competitiveness within South African industry, demonstrate that value creation is a complicated and integrated processes that requires the cooperation of all actors in the industry including customers. Based on these observations, it would seem as if the only viable option to increase value addition in the industry is to opt for hi-tech value added products. Production capacities in the industry need to be upgraded if this objective is to be realized. This move is especially pertinent given the nature of global competition facing the industry as well as changes in the rule of origin by the European Union which might pose a serious threat. Whereas much still needs to be done by the industry, the government also needs to intervene by appropriate policy options in order to counter the challenges. Policy interventions that the government may consider include due facilitation in supply of energy, cut in interest rates as well as duty-free market access to mention but a few.

The proposals above are in line with the recommendations of Chand (2001, p. 276) on turn-around strategies for the Fiji garment industry. The author proposes three strategies for the Fiji garment industry that might be applicable to the South African case. First, he recommends that that the industry should invest in high-tech production processes to enable the industry shift from producing lower end market garments to high value-added up-market designer fashion apparel. Second, the garment industry should stop relying on privileged access to existing markets and be proactive in searching for and developing niche markets especially at the upper end of the market. Finally, he urges garment firms to take full advantage of niche production whereby firms produce various products with a short lead time or just in time (JIT).

To further buttress the point raised above, Barnes et al. (2001, p. 301) show that JIT production tends to break down in 'a firm if its suppliers fail to deliver their products in small lot sizes, or on a reliable basis and with perfect quality.' Understanding the industry input-output structure is important in trying to make sense of the constraints facing value addition in this sub sector. For instance, it would seem as if local spinners produce excess cotton yarn than local demand. This excess cotton yarn would then have to be exported or the local factories would have to cut production. Further along the value chain, the weaving sector of the country cannot use this yarn to produce fabric as the local demand is limited while exports are not possible due to lack of market access. It thus illogical to complain about constrained value addition given this structure. Negotiating for reduced import duties in selected global markets seems to be an attractive option as a means of deepening market access.

The kinds of intervention needed to enhance global market access require the participation of business as well as state actors in order to plot viable strategies. For instance, market access may be increased via a third state party. As an example, South Africa could enter into a strategic alliance with a country that has got greater market access to the European Union (EU) or the United States (US) by exporting textile and clothing intermediary products to that country for onward exports. And, as is already happening with the case of China, South African entrepreneurs could establish joint ventures locally with entrepreneurs from the countries already enjoying large market access for value added exports to these countries.

It is perhaps ironical that even increasing retail prices for clothing does not automatically translate into better performance for the industry due to its unique structure. This is because, with inadequate demand from cash-strapped consumers, retailers tend to push manufacturers to absorb extra production costs. Any decrease in margin call would be devastating for cotton millers unless availability of cotton at reasonable prices to domestic producers of textiles is guaranteed. If the price of cotton is not reigned in domestically, value-added textile products such as cloth, hosiery and garments could easily become uncompetitive in the global market place. Given this background, perhaps innovation targeting may results in greater capability development in the industries.

According to Francis and Bessant (2005, p. 171), for innovation to impact favourably on capability development, industries must move from merely developing new products and services and delivery methods (process innovation) to altering market position and business models. The author cites Baumol (2002) to define innovation as: 'the recognition of opportunities for profitable change and the pursuit of those opportunities all the way through to their adoption in practice.' This is akin to what Johnson (2010, p. 7) conceptualizes as 'seizing the white space.' Johnson describes this white space as:

The range of potential activities not defined or addressed by the company's current business model, that is, the opportunities outside its core and beyond its adjacencies that require a different business model to exploit.

In a way, all these observations lead to a policy conundrum of sorts. Ideally, one hopes to ensure that only value added is exported while a raw material such as yarn is consumed internally. But this would require that the value added sector is developed well enough to have such a potential to exhaust the yarn. These developments call for the government to be involved in increasing the potential of the value added sector by encouraging more and more entrepreneurs in the business so that yarn produced in the country could be fully utilised locally. As a corollary to this, the 
clothing industry needs to be groomed for value addition in the produce of textile manufacturers yet it is a grim fact that the clothing industry has not grown much in the last twenty years. Unless the potential for export is increased downstream, these products are not in a position to add to the national income.

\section{Employment Capacity}

By the year 2010, the textile and clothing industry directly employed a total of just under one hundred and fifty thousand people either formally or informally. Going by Figure 2.5 below, both industries have shed about one hundred thousand jobs from the year 1997 to 2010. The years between 1995 and 1998 saw the peak of employment creation with the total number peaking at just over a quarter of a million jobs. From then till about 2005, the employment figures were just about steady before the onset of a free-fall that saw the sub sector haemorrhaging jobs rapidly with the clothing industry losing jobs at a much faster rate that its textile counterpart.

The above observations are depressing in that they belie Gereffi's (1999, p. 37) observation that 'the explosive growth of imports in developed countries indicates that the centre of gravity for the production and export of many manufactures has moved to an ever expanding array of newly industrializing economies (NIEs) in the Third World.' The fact that South African textiles and clothing industries are yet to catch up on these gains may mean that the adoption of export-oriented policies in the 1990s did not significantly improve productivity nor were substantial gains in capital accumulation realized in the industry.

Given the standard academic posit on the textile and clothing industry, the ability to create significant number of jobs is not in doubt. What is required is for the business community to taken on board in policy making mechanisms so that government can partner much more effectively with other stakeholders such as the labour unions. For instance, the generation of jobs will depend on the kind of market access that bilateral negations might yield in the global market. Market access is one of the issues likely to further impede textile and clothing exports alongside energy and power shortages which can potentially make exports more expensive thus eroding market penetration. As Gereffi (1999, p. 39) demonstrates, 'participation in global commodity chains is a necessary step for industrial upgrading because it puts firms and economies on potentially dynamic learning curves.' It would be necessary in this research to demonstrate the requisite dynamic capabilities that industries in the sub-sector need to acquire in order to successfully continue participating in the export market.

In the case of the East Asian NIEs, Gereffi (1999, p. 57) argues that it was a combination of labour shortages, high wages, and high land prices as well as external pressures such as currency re-evaluation, tariffs and quotas that drove their textile and clothing industries to increasingly adopt export-led growth. To do this successfully, the companies were forced to set up elaborate offshore production networks while at the same time developing manufacturing expertise that required substantial spending in research and development. Equally important, the companies had to learn how to flexibly manage overseas production networks.

Figure 2.5: Number of Employment in the textile and clothing industry (Formal \& Informal)

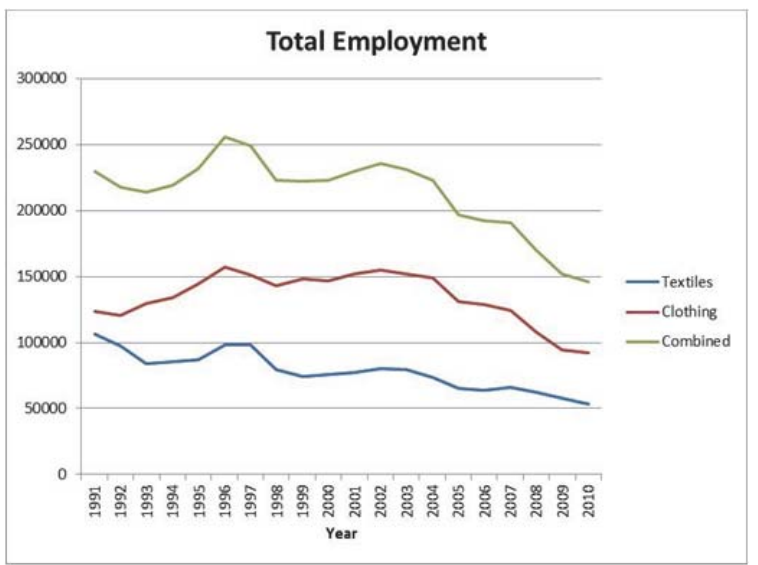


Amazingly, over the twenty-year period considered here, both industries have retained a skills base of four percent and three percent respectively in the highly skilled category. On the other hand, the percentage employment share of the informal sector has been growing steadily for both sectors. The clothing industry has witnessed almost a doubling of the share of informal employment compared to total employment in the same period while the textile industry saw a four-fold increase. The relatively poor performance of South African textiles and clothing in creating jobs is even more confounding if one considers Gibbon's (2003, p. 1809) observation that:

Along with Mauritius, South Africa had easily the largest and most sophisticated clothing sector in Africa prior to $\mathrm{AGOA}^{4}$, and was therefore considered by most observers to be among the best placed to take advantage of it.

It would therefore be prudent if this research were to investigate other potential drawbacks in the industry given that the new orientation from the year 2000 onwards heightened the significance of branded marketing as well as the fact that both South Africa and Mauritius faced much more restrictive rules under AGOA (Gibbon 2003, p. 1815). It would be necessary therefore to look at not only the retail strategies of the firms but also the institutional support that domestic industries receive in order to access export markets.

Table 2.3: Percentage of Total Employment per Industry By Category

\begin{tabular}{|c|c|c|c|c|c|c|c|c|}
\hline \multicolumn{7}{|c|}{ Percentage of Total Employment Per Industry } \\
\hline & \multicolumn{2}{|c|}{ Informal } & \multicolumn{2}{c|}{ Semi- and Unskilled } & \multicolumn{2}{c|}{ Skilled } & \multicolumn{2}{c|}{ Highly Skilled } \\
\hline Year & Textile & Clothing & Textile & Clothing & Textile & Clothing & Textile & Clothing \\
\hline $\mathbf{1 9 9 1}$ & 8 & 19 & 75 & 67 & 13 & 11 & 4 & 3 \\
\hline $\mathbf{1 9 9 2}$ & 10 & 21 & 74 & 66 & 12 & 11 & 4 & 3 \\
\hline $\mathbf{1 9 9 3}$ & 11 & 22 & 73 & 64 & 12 & 11 & 4 & 3 \\
\hline $\mathbf{1 9 9 4}$ & 12 & 24 & 72 & 62 & 12 & 11 & 4 & 3 \\
\hline $\mathbf{1 9 9 5}$ & 13 & 25 & 71 & 61 & 12 & 11 & 4 & 3 \\
\hline $\mathbf{1 9 9 6}$ & 14 & 26 & 70 & 60 & 12 & 11 & 4 & 3 \\
\hline $\mathbf{1 9 9 7}$ & 15 & 28 & 69 & 59 & 12 & 10 & 4 & 3 \\
\hline $\mathbf{1 9 9 8}$ & 16 & 29 & 67 & 58 & 12 & 10 & 4 & 3 \\
\hline $\mathbf{1 9 9 9}$ & 18 & 29 & 66 & 58 & 12 & 10 & 4 & 3 \\
\hline $\mathbf{2 0 0 0}$ & 17 & 29 & 66 & 59 & 12 & 10 & 4 & 3 \\
\hline $\mathbf{2 0 0 1}$ & 21 & 33 & 63 & 55 & 12 & 9 & 4 & 3 \\
\hline $\mathbf{2 0 0 2}$ & 22 & 34 & 62 & 54 & 12 & 9 & 4 & 3 \\
\hline $\mathbf{2 0 0 3}$ & 23 & 33 & 61 & 55 & 12 & 9 & 4 & 3 \\
\hline $\mathbf{2 0 0 4}$ & 25 & 35 & 59 & 54 & 12 & 9 & 4 & 3 \\
\hline $\mathbf{2 0 0 5}$ & 27 & 37 & 57 & 52 & 12 & 8 & 4 & 3 \\
\hline $\mathbf{2 0 0 6}$ & 28 & 38 & 56 & 51 & 11 & 8 & 4 & 3 \\
\hline $\mathbf{2 0 0 7}$ & 30 & 41 & 54 & 49 & 11 & 8 & 4 & 3 \\
\hline $\mathbf{2 0 0 8}$ & 29 & 39 & 55 & 50 & 11 & 8 & 4 & 3 \\
\hline $\mathbf{2 0 0 9}$ & 33 & 39 & 52 & 50 & 11 & 8 & 4 & 3 \\
\hline $\mathbf{2 0 1 0}$ & 33 & 39 & 52 & 50 & 11 & 8 & 4 & 3 \\
\hline
\end{tabular}

In absolute terms, as shown in Figure 2.6, Informal employment saw a robust growth in the clothing sector only from 1991 to 1996. Thereafter, the growth flattened till 2001when a modest growth was again observed which was to plateau till 2007 when a marked downhill trend began. As for the textile industry, the modest growth in informal employment achieved from 1991 to 1997 was again replicated from 2001 to 2010 after modest dips between 1998 and the year 2000. The interesting thing to note here is that the South African wearing apparel's labour sector is much 'more sharply segmented than the industry's product end-market' (Gibbon 2003, p. 1818). The author points out that there are differences in skill levels, urban and rural remuneration, as well as in unionization.

The figures and trends give an indication of specialization in the work force in terms of who is needed in the core technology production activities and in support and auxiliary services given the skills base. At the national policy level, the opportunities projected for the textiles and clothing industries might give an indication of how to train say, displaced agricultural labourers, the youth and women to seek gainful employment in the sub sector. If global competitiveness and market access issues are resolved successfully by the relevant stakeholders, it would then be feasible to factor in the 
textiles and clothing industries by policy makers in the various schemes for education, training and linked employment generation.

Figure 2.6: Informal Employment Trend

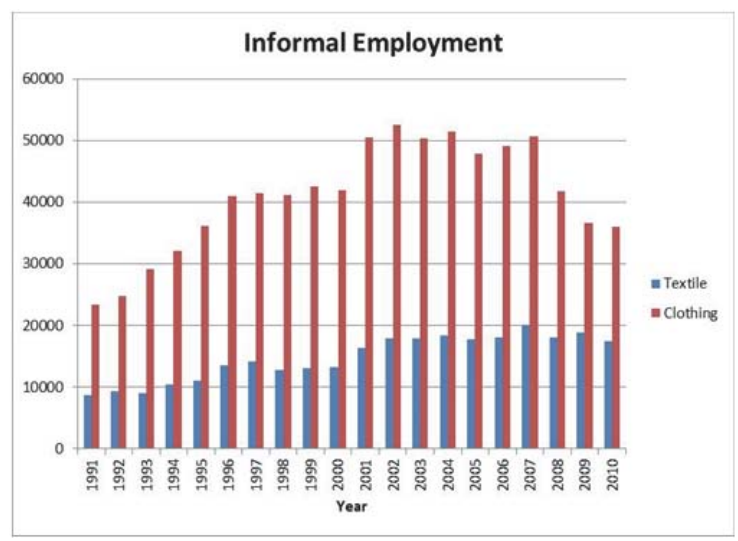

There is no gainsaying the fact that both the export and the domestic retail industries for textile and clothing have a great potential to benefit from a clearer focus of skill development activities. The human resources especially skill training and development in this sub sector has yet to be sufficiently targeted and strategically focussed. There is need to integrate vocational and skill training education infrastructure and the industrial engineering cum modern technology management since these are emerging to be highly differentiated in the sub-sector. At a first glance, it would seem as if the textiles and clothing industries is one sub sector where the increasing competitive pressures on both time and costs will not be easily compounded by the national skills deficit. In order to adjust to the re-composition of domestic demand after liberalization, Gibbon (2003, p. 1818) says that South African clothing companies reconfigured their operating styles thus:

Their strategies included greater investment in design and sampling, and increasing expenditure of time and resources on sales and follow-up, merchandising fabric, trim and components, and managing changes of set up. In the process, these enterprises built up administrative and technical staff covering these functions.

All these developments were undertaken amidst a growing demand to at the same time restructure the companies significantly. For instance, Barnes et al. (2001, p. 298) note that South African manufacturing competitiveness is still being hampered by industrial relations which are yet to be consistent with emerging democratic expectations. The authors also maintain that South African companies need to do much more than just invest in human capital, they need to develop a management structure that is representative of the wider population and introduce more democratic and inclusive decision making styles.

As stated previously, the prospects of employment are high in the textile and clothing industries and are perhaps only second to agriculture given the nature of the bulk of their skills requirements. Even in these depressed times, there are still a number of export-oriented garments industries where a large number of workers remain employed. The establishment of more garments industries would create further employment opportunities. Given the right policy mix, there are still employment prospects even further upstream for employment creation such as in the spinning and weaving mills as well as the dyeing mills.

\section{Investment}

Fixed capital investments have been waning in both the textile and the clothing industries since 1991 as captured in Figures 2.7 and 2.8. Compared at 2005 prices, fixed investments in the textiles industry reduced from just over six billion rands in 1991 to about three and a half billion in twenty years. Similarly, the clothing industry also saw a drop from nearly two billion rands to just about one and a half billion rands in the same period. In theory, as Wignaraja (2008, p. 30), demonstrates in the case of Mauritius, a more liberal foreign direct investment (FDI) regime should stimulate the entry of foreign firms and thus by extension promote clothing exports. 
Figure 2.7: Investments in the Textile Industry in Rm at 2005 prices

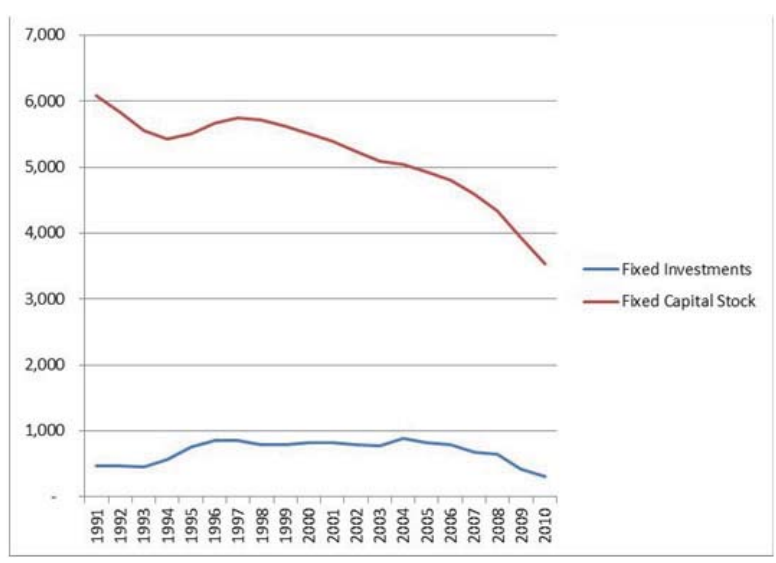

Wignaraja's (2008, p. 30) observation in the case of Mauritius has not been replicated in South Africa. From a plateau of about four hundred million rands between 1991 and 1993, the fixed capital stock rose steadily to double by the year 1996. The 1996 levels remained fairly constant till 2007 when the fixed capital stock again began an ominous decline to new lows in 2010. What is interesting is that the capital productivity index measured with 2005 as a base year doubled during the period under study as shown in Figure 2.8. This deviation from theory is problematic since, as demonstrated by case studies cited by Wignaraja (ibid):

i. $\quad$ Foreign firms are better exporters than domestic firms; and

ii. Technological capabilities and human capital approaching international best practice levels are important determinants of export advantage.

We are thus forced to enquire into the nature of the dynamic capabilities of firms operating in the sub sector that made the gains in capital productivity index to be realized despite the non-impressive investment portfolio in the industry. Dynamic capabilities are an off-shoot of the Resource-based view (RBV) of the firm literature (see, generally, Eisenhardt \& Martin, 2000). Eisenhardt and Martin (2000, p. 1105) summarize RBV as follows: 'RBV assumes that firms can be conceptualized as bundles of resources, that those resources are heterogeneously distributed across firms, and that resource differences persist over time.' They then proceed to define dynamic capabilities thus:

The firm's processes that use resources - specifically the processes to integrate, reconfigure, gain and release resources - to match and even create market change. Dynamic capabilities thus are the organizational and strategic routines by which firms achieve new resource configurations as markets emerge, collide, split, evolve, and die (Eisenhardt \& Martin, 2000, p. 1107).

Figure 2.8: Investments in the Clothing Industry in Rm at 2005 prices

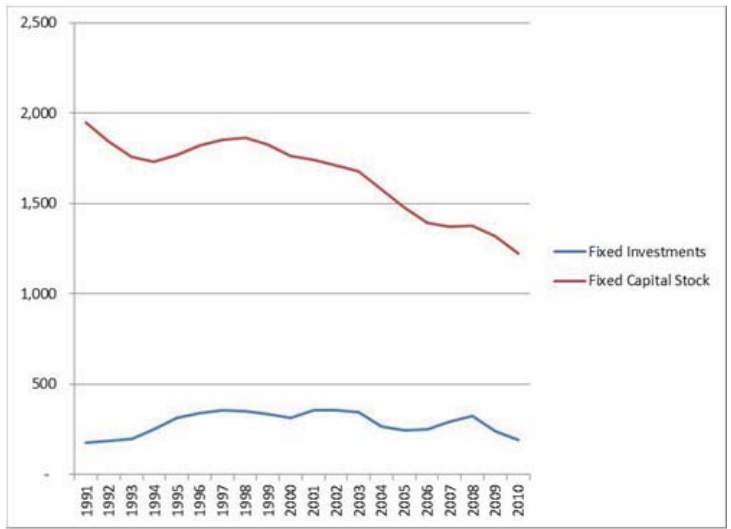


The clothing industry has fared no better in terms of fixed capital stock when measured in constant prices using the year 2005 as a base. From a modest base of about two hundred million rands in 1991, the figures rose minimally to stabilize at around three hundred and fifty million rands by 1997 and then remained fairly constant till 2008 with marked dips between the years 2003 and 2006. A negative trend then emerges from 2008 till 2010. Just like in the textile industry, the capital productivity index of the clothing industry doubled in the period under study as shown in Figure 2.8. The concept of dynamic capabilities, is also useful in explaining why firms in the same industry perform differently (Zott, 2003, p. 97). Zott (ibid), agrees with Eisenhardt and Martin (2000, p. 1105) to assert that 'firm performance is affected by firms' ability to integrate, build, and reconfigure their resources and competencies.' All the authors attribute the conceptualization of the term 'dynamic capabilities' to Teece, Pisano \& Shuen (1997).

Figure 2.8: Capital Productivity Index using the year 2005 as a base

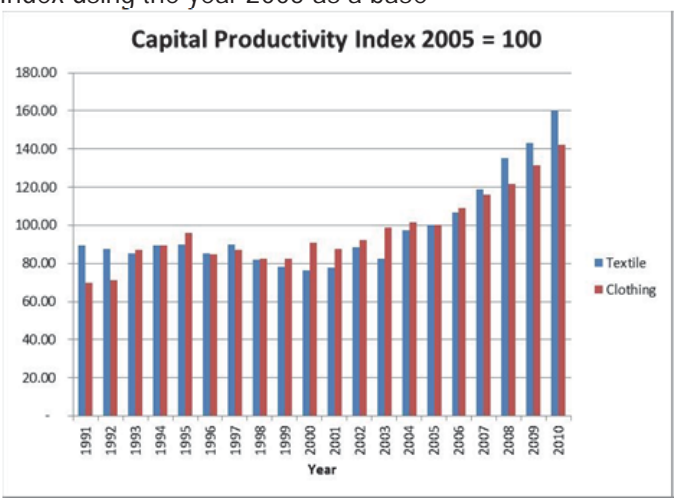

\section{Trade}

Many factors contribute to the poor international competitive standing of the industry. Historically, prior to trade liberalization, earlier policies of the apartheid government had created an environment of import replacement and employment creation at almost any cost in a non-competitive economic environment that included price and supply controls at the input ends of the industries' pipeline. The lessons of the past therefore dictate that any planned policy interventions in the sector must be steered much more delicately than handled previously. According to Moodley (2003, p. 557), the important challenge facing the South African apparel sector 'is not whether to participate in global process, but how to do so in ways which provide for sustainable growth.' In a study looking at the adoption of e-business in the South African clothing sector, the author points out that local firms must build and maintain new sources of competitive advantage in order to break out of the low-productivity, low value adding conundrum into which the sub sector struggles today (Moodley, 2003, p. 558). He emphasizes that technological innovation, which forms part of the dynamic capabilities we referred to earlier, is important as many economists often assign a big portion of 'measured growth to technological progress rather than to increases in the traditional inputs of labour and capital.'

Figure 2: Exports in million rands by sub sector

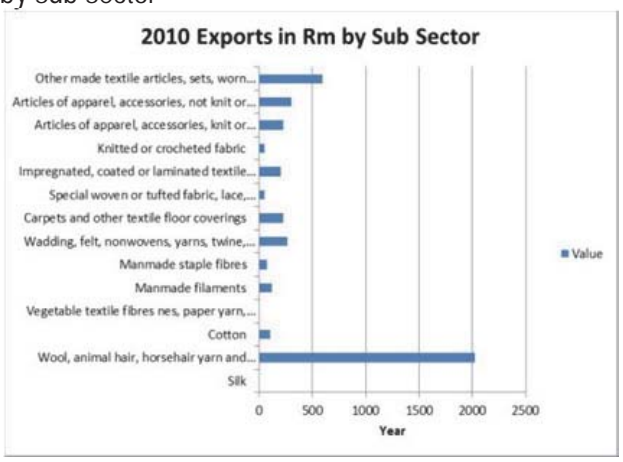


Figure 2: Imports in million rands by sub sector

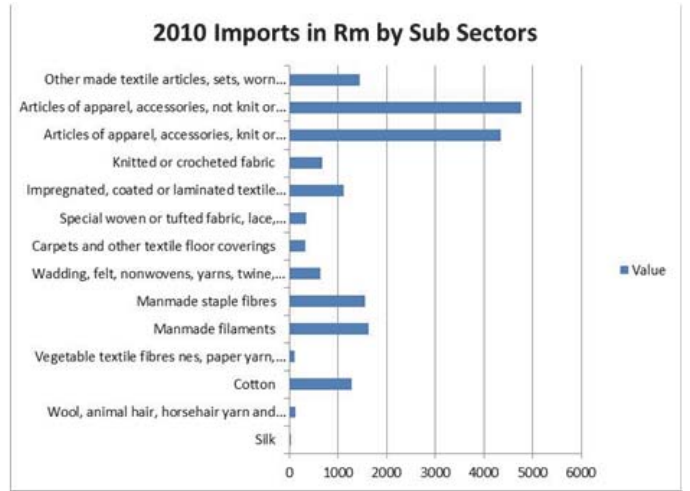

According to the South African Government's 2010/11 - 2012/13 Industrial Policy Action Plan (2010 pp. 64 -65), trade balance increased negatively from 2000 to 2008 in all the industries across the sector with the clothing industry being the worst affected. In a bid to improve performance in this sector, the government will roll out the Textile and Clothing's Production Incentive (PI) as well as the Textile and clothing's Competitiveness Program (CTCP) from 2010/11 onwards through the Industrial Development Corporation (IDC). The Government hopes that these two programs will enable the sector to compete sustainably and effectively against international competitors in both the domestic and the export markets and that company level competitiveness will be improved substantially. These expectations are based on the assumption that the sector lags behind their international competitors in terms of conversion efficiencies and other key indicators of world class manufacturing principles of which quality, cost and delivery are the main drivers. ${ }^{5}$

Figure 2.9: Annual Export Value in rands

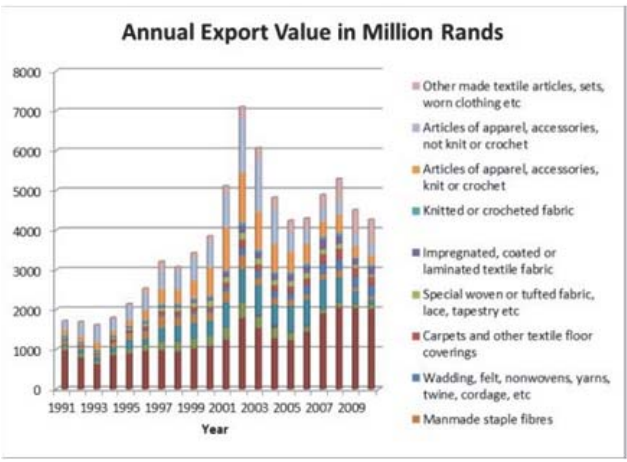

Table 2.4: Clothing, textiles, footwear and leather sector contribution in $2008^{6}$

\begin{tabular}{|c|c|}
\hline Variable & Contribution in 2008 \\
\hline Manufacturing value-added & R 8.2 billion (0.8\%) \\
\hline Manufacturing employment & 126245 \\
\hline Trade balance & - R 18 billion \\
\hline
\end{tabular}

As can be seen from Figure 3 above, the data on trade is much more informative regarding the industry's product drivers of growth. Disregarding silk, which is basically an agricultural product, industrial textiles and clothing are the key drivers of growth in the industry. Initially, from 1990 
Figure 2.10: Annual Exports in million rands by region

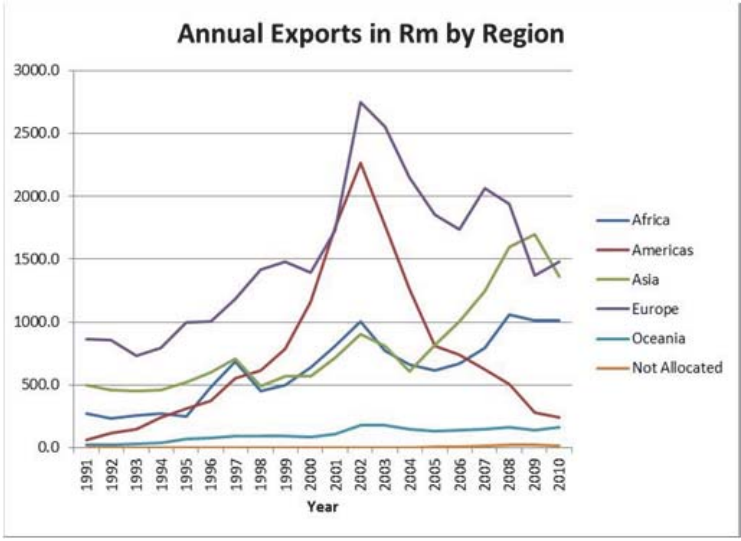

up to the peak of exporting output in 2002, the growth was quite steady. Exports began to fall from 2002 to 2009, yet industrial textiles more or less maintained their share of the export market with clothing and manmade filaments exhibiting a semblance of growth. These kinds of differentiation make the value chains approach much more applicable in determining the performance of the industry.

Kaplinsky and Morris (2008), in a study investigating whether Asian drivers undermine export-oriented industrialization in sub Saharan Africa (SSA), point out that two factors influence the effectiveness of export-led growth based on the expansion of manufactured goods (pp. $254-255$ ). First, they note a cluster of endogenous factors such as the quality of infrastructure, the effectiveness of property rights, peace and security, technological capabilities, and effective entrepreneurship. These factors impact heavily on the SSA firms' response to global market opportunities. Second, the exogenous factors reflect mostly the changing dynamics of international business. Whereas South Africa is not as badly off as the other SSA countries in terms of the endogenous factors referred to here, still it is a highly complex situation if the best policy mix is to develop weak domestic capabilities in alignment with favourable external market opportunities. It is this enigma that forces the present research to enquire into the nature of institutions in the determination of performance in the sub sector. As wignaraja (2008, p. 31) convincingly shows, the incorporation of the notion of firm-specific advantages, inherently alters the suppositions of theories of international trade thus:

i. $\quad$ There are country-specific and industry-specific advantages which apply to all firms equally.

ii. Within this, some advantages will be firm-specific since certain managerial, organizational, marketing and other skills will be peculiar to each firm as will production methods, technologies and experience based knowhow.

Figure 2.11: Annual imports in million rands by region

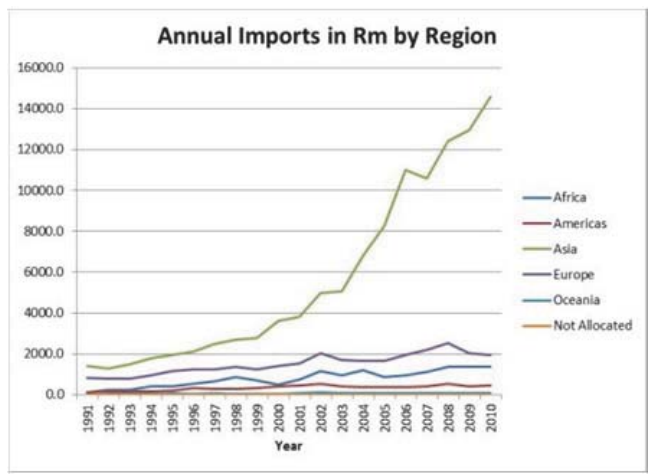


The perceived decreasing profitability in the industry is best captured by contrasting the export figures with the gross domestic fixed investment as discussed earlier. Whereas domestic fixed investments continued to grow steadily since 1990 until 2004, similar figures for the clothing sector has more or less plateau since 1997 perhaps reflecting the big shifts in management style in the clothing sector that has moved more towards flexible production and outsourcing of upstream production activities. Wignaraja $(2008$, p. 32) neatly summarizes literature that indicates that 'firm-level export performance (and building technological capabilities) in developing countries is affected by national policy and institutional factors. This is one more reason why the study has to determine the impact of the current and past mix of policy and institutional factors on the investment climate, managerial capabilities, industrial relations, amongst other measures of superior performance.

\section{Conclusion}

Despite the unexciting outlook of the textile and clothing industries in South Africa today, the strategic relevance of the sub sector in terms of developing country macroeconomic policies makes it imperative that radical interventions be explored in order to save it from total collapse. For instance, the sub sector has one of the longest supply chain that includes production of raw materials; spinning, weaving, or knitting; finishing; design; sewing; distribution; and marketing. Another factor making the sub sector attractive to policy makers as was demonstrated by earlier analysis is the fact that it absorbs a high proportion of unskilled workers and is generally labour intensive.

As for technological learning and adaptation, the textile and clothing industries' requirements are fairly cheap and simple with little revolutionary change over the past fifty years or so. This ensures that improvements in technology are mainly catered for by specialized machines for each task and better coordination of the tasks. From these developments, it seems apparent that innovation and design are key elements of a coherent competitive strategy for the industries. There is therefore a need to interrogate the existing dynamic capabilities to determine whether they are in line with sustainable long term growth in the sector.

The issues to be determined will logically revolve around retail strategies given that research has shown viable value chains as well as the dynamic capabilities necessary for successful business models. From the brief review above, it would appear as if the superior performers of the future in the South African textiles and clothing industries will have to consider sophisticated textile materials for industrial and medical use, athletic sportswear and equipment, and up-market fashion clothing alongside radically modified traditional offerings. As has been a standard economic posit over the years, companies in the sub sector will still have to be reminded and encouraged to engender economies of scale in distribution that cover the entire supply chain or else concentrate on niches with a potential to develop a significant market position. The third question will therefore explore the existing retail strategies to see whether they are attuned to these aspirations.

Finally, policymakers will have to grapple with the issues of institutions in order to locate the industries within the boundaries of national policies, local training and research facilities, existing trade associations, existing bilateral and multi-lateral, the local nature of industrial relations as well as the overall vision of a developmental state. The New Institutional Economics (NIE) offers some interesting theoretical handle that could be deployed to explore the site of the value chain struggle worth fighting to give the sub sector a breathing space so to speak.

\section{References}

Barnes, J, Bessant, J, Dunne, N \& Morris, M 2001, 'Developing manufacturing competitiveness within South African industry: the role of middle management', Technovation, no. 21, pp. 293 - 309, (Online ScienceDirect).

Birkinshaw, J 2010, Reinventing management: Smarter Choices for getting work done, Jossey-Bass, San Francisco, Carlifornia.

Bratton, J, Grint, K \& Nelson, D L 2005, Organizational Leadership, Thompson South-Western, Mason, Ohio.

Carmody, PR \& Owusu, FY 2007 'Competing hegemons? Chinese versus American geo-economic strategies in Africa', Political Geography, no. 26, pp. 504 - 524, (Online ScienceDirect).

Chand, A 2001, 'Human resource strategies in small states: the case of garment factories in the Fiji Islands', International Journal of Educational Development, no. 21, pp. 273 - 284, (Online ScienceDirect).

Francis, D \& Bessant, J 2005, 'Targeting innovation and implications for capability development', Technovation, no. 25, pp. 171 - 183, (Online ScienceDirect).

Gereffi, G 1999, 'International trade and industrial upgrading in the apparel commodity chain', Journal of International Economics, no. 48, pp. 37 - 70, (Online ScienceDirect).

Gibbon, P 2003, 'The African Growth and Opportunity Act and the Global Commodity Chain for Clothing', World Development, vol. 31, no. 11, pp. 1809 - 1827, (Online ScienceDirect).

Golub, SS \& Mbaye, AA 2009, 'National Trade Policies and smuggling in Africa: The case of the Gambia and Senegal', World 
Development, vol. 37, no. 3, pp. 595 - 606, (Online ScienceDirect).

Haddad, C J 2002, Managing technological change: A strategic partnership approach, SAGE Publications, Thousand Oaks; London \& New Delhi.

Helfat, C E, Finkelstein, S, Mitchell, W, Peteraf, M A, Singh, H, Teece, D J \& Winter, S G 2007, Dynamic capabilities: Understanding strategic change in organizations, Blackwell Publishing, Oxford.

Hufenbach, W, Gude, M \& Ebert, C 2009, 'Hybrid 3D-textile reinforced composites with tailored property profiles for crash and impact applications', Composite Science and Technology, no. 69, pp. 1422 -1426, (Online ScienceDirect).

Industrial Policy Action Plan (IPAP 2) 2011/12 - 2013/14 2011, Economic sectors and employment cluster, Pretoria: Department of Trade and industry (DTI).

Johnson, M W 2010, Seizing the white space, Harvard Business Press, Boston, Massachusetts.

Kaplinsky, R \& Morris, M 1999, 'Trade Policy Reform and the competitive Response in Kwazulu Natal Province, South Africa', World Development, vol. 27, no. 4, pp. 717 - 737, (Online ScienceDirect).

Kaplinsky, R \& Morris, M 2008, 'Do the Asian Drivers Undermine Export-oriented Industrialization in SSA', World Development, vol. 36, no. 2, pp. $254-273$, (Online ScienceDirect).

King, P L 2009, Lean for the process industries: Dealing with complexity, CRC Press, Boca Raton; London \& New York.

Kreinin, M E 2006, International Economics: A policy approach, Thompson Higher Education, Mason, Ohio.

Macdonald, M 1995, 'Economic Restructuring and Gender in Canada: Feminist Policy Initiatives', World Development, vol. 23, no. 11, pp. 2005 - 2017, (Online ScienceDirect).

Marr, B 2010, The intelligent company: Five steps to success with evidence-based management, John Wiley \& Sons Ltd, Chichester.

Moodley, S 2003, 'The challenge of e-business for the South African apparel sector', Technovation, no. 23, pp. 557 - 570, (Online ScienceDirect).

Muneer, T, Asif, M, Cizmecioglu, Z \& Ozturk, HK 2008, 'Prospects for solar water heating within Turkish textile industry', Renewable and Sustainable Energy Reviews, no. 12, pp. 807 - 823, (Online ScienceDirect).

Murphy, JT 2007 'The Challenge of Upgrading in African Industries: Socio-Spatial Factors and the Urban Environment in Mwanza, Tanzania', World Development, vol. 35, no. 10, pp. 1754 - 1778, (Online ScienceDirect).

Naude, W \& Coetzee, R 2004, 'Globalization and inequality in South Africa: modelling the labour market transmission', Journal of Policy Modeling, no. 26, pp. 911 - 925, (Online ScienceDirect).

New Growth Path (NGP) 2010, The new growth path: Framework, Pretoria: Economic Development Department (EDD).

Palpacuer, F, Gibbon, P \& Thomsen, L 2005, 'New Challenges for Developing Country Suppliers in Global Clothing Chains: A Comparative European Perspective', World Development, vol. 33, no. 3, pp. 409 - 430, (Online ScienceDirect).

Pardey, D 2007, Introducing leadership, Butterworth-Heinemann, Oxford.

Pearson, J, Viviers, W, Cuyvers, L \& Naude, W 2010, 'Identifying export opportunities for South Africa in the southern engines: A DSM approach', International Business Review, no. 19, pp. 345 - 359, (Online ScienceDirect).

Phelps, NA, Stillwell, JCH \& Wanjiru, R 2009, 'Broken Chain? AGOA and Foreign Direct Investment in the Kenyan Clothing Industry', World Development, vol. 37, no. 2, pp. 314 - 325, (Online ScienceDirect).

Ramamurthy, P 2000, 'The Cotton Commodity Chain, women, Work and Agency in India and Japan: The Case for Feminist Agro-Food Systems Research', World Development, vol. 28, no. 3, pp. 551 - 578, (Online ScienceDirect).

Rieple, A \& Singh R 2010, 'A value chain analysis of the organic cotton industry: The case of UK retailers and Indian suppliers', Ecological Economics, no. 69, pp. 2292 - 2302, (Online ScienceDirect).

Rummler, G A, Ramias, A J \& Rummler, R A 2010, White space revisited: Creating value through process, Jossey-Bass, San Francisco, Carlifornia.

Scott, AJ 2006, 'The Changing Global Geography of Low-Technology, Labor-Intensive Industry: Clothing, Footwear, and Furniture', World Development, vol. 34, no. 9, pp. 1517 - 1536, (Online ScienceDirect).

Serra, F, Pointon, J \& Abdou, H 2011, 'Factors influencing the propensity to export: A study of UK and Portuguese textile firms', International Business Review. Article in press at time of citation (Online ScienceDirect).

Seyoum, B (2007), 'Trade liberalization and patterns of strategic adjustment in the US textiles and clothing industry', International Business Review, no. 16, pp. 109 - 135, (Online ScienceDirect).

Teece, D, Pisano, G, \& Shuen, A 1997, 'Dynamic capabilities and strategic management', Strategic Management Journal, vol. 18, no. 7, pp. $509-533$.

Wignaraja, G 2008, 'Foreign ownership, technological capabilities and clothing exports in Sri Lanka', Journal of Asian Economics, no. 19, pp. 29 - 39, (Online ScienceDirect).

Wilkinson, N 2005, Managerial economics: A problem-solving approach, Cambridge University Press, Cambridge. 